\title{
PHOTO-VOICE : OPTIMALISASI PERAN TAMAN BACA MASYARAKAT (TBM) SEBAGAI SARANA PENGUATAN LITERASI DANPENGEMBANGAN LABORATORIUM PEMBELAJARAN SEPANJANG HAYAT
}

\author{
Kartika Nuswantara \\ UPT PMK Sosial Humaniora, FBMT, Institut Teknologi Sepuluh Nopember \\ kartikanuswantara.its@gmail.com
}

\begin{abstract}
ABSTRAK
Taman Baca Masyarakat dapat dipandang sebagai sarana yang optimal dalam pengembangan kebiasaan membaca dan sekaligus kebiasaan dan kebisaan belajar. Pemanfaatan mutli moda teks yang diambil dari media cetak maupun daring menjadi sumber potensial untuk memajankan anakanak akan berbagai jenis ragam teks, baik fiksi maupun non fiksi. Teks-teks tersebut dikemas dalam kegiatan yang beragam sehingga mendorong kognitif, afektif sekaligus prikomotoris peserta pengabdian. Kegiatan membaca nyaring, membuat mading tematik, dan menulis cerita telah mampu mendorong 100 anak TBM peserta program untuk menghasilkan kumpulan cerita anak. Kegiatan dan luaran yang dicapai dari kegiatan pengabdian ini memberikan bukti empiris terkait fisibilitas TBM yang dioptimasi fungsinya sebagai pusat pengembangan literasi dan laboratorium belajar sepanjang hayat.
\end{abstract}

Kata Kunci: TBM, literasi, belajar sepanjang hayat, multi moda teks, membaca nyaring

\section{PENDAHULUAN}

Pada beberapa kurun waktu yang lalu, kita dikejutkan dengan hasil survey internasional yang memalukan dari The Trends in International Mathematics and Science Study (TIMSS) 2015 (Foy, 2017) dan the Progress in International Reading Literacy Study (PIRLS) 2016 (Foy et al., 2018) serta Program for International Students Assessment (PISA) tahun 2015 (OECD, 2018), namun kita sekarang boleh berbangga dengan perkembangan tingkat literasi negara kita. Pada akhir tahun 2016, seperti yang disebutkan oleh Gufran A. Ibrahim (2017) dalam tulisannya di harian Kompas edisi 29 April 2017, bahwa telah terjadi peningkatan terhadap tingkat literasi bangsa kita. Sebuah organisasi internasional untuk Kerja Sama Ekonomi dan Pembangunan (OECD) telah yang melaksanakan penilaian tiga tahunan atas budaya literasi 72 negara melalui PISA, melansir indeks buday aliterasi siswa antar bangsa (lihat gambar 1). Indeks literasi sains dan matematika siswa Indonesia naik cukup berarti masing-masing 21 dan 11 poin: 382 poin pada 2012 menjadi 403 tahun 2015, serta 375 tahun 2012 dan 386 pada 2015. Indeks literasi membaca hanya naik satu poin: 396 pada 2012 dan 397 pada 2015 (OECD, 2018). 


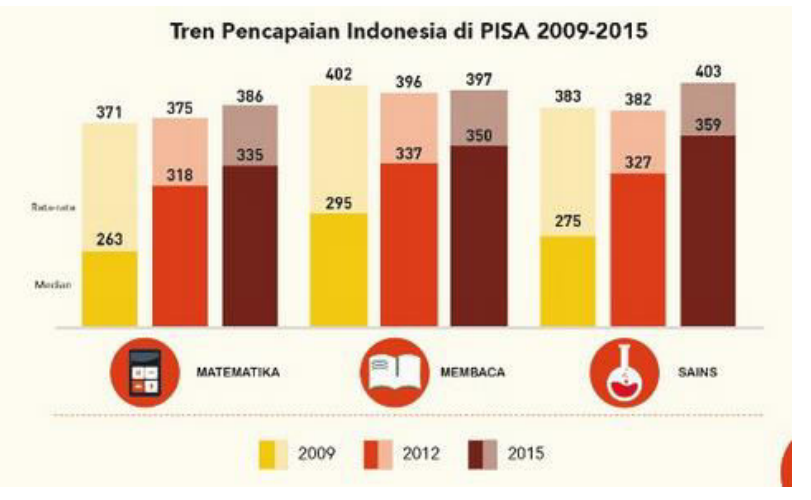

Gambar 1. Tren Pencapaian Indonesia di PISA 2009-2015

Berdasarkan hasil di atas, diketahui bahwa kenaikan indeks literasi membaca lebih lamban dibandingkan dengan sains dan matematika; dan bahkan kemajuan literasi membaca kita masih jauh dibandingkan dengan bangsa lain. Pada artikel yang sama Ibrahim (2017) menyebutkan adanya beberapa sebab. Salah satunya adalah teks bacaan dalam uji PISA adalah multiteks dan berbasis komputer. Oleh karenanya tampilan teks disajikan dengan teknologi yang canggih. Isi dan struktur teksnya juga meliputi beragam genre wacana dengan memadukan kata, kalimat, grafik, peta, dan ragaan yang dibentuk dalam tautan lintas-teks dengan siasat rujuk silang (cross-reference).Masih menyitir pendapat ibrahim, bahwa untuk menukik ke kedalaman makna multiteks maka sekurangkurangnya dibutuhkan dua kecakapan penting: (1) terampil menangkap makna yang tersaji dalam paragraf; dan (2) kecepatan mengemas tautan makna antar teks, antar teks dengan grafik, antar teks dan simbol, serta relasi makna antar grafik. Sebelum sampai pada upaya mencapai kedalaman memahami makna dalam multiteks, perlu dipahami apa sesungguhnya yang dimaksud dengan multiteks tersebut. Meminjam definisi multiteks atau multi modal text yang dipergunakan oleh Walsh (2003), dapat dipahami bahwa teks ini merupakan jenis teks yang memiliki lebih dari satu moda, dan membutuhkan kemampuan memahami makna yang dikomunikasikan melalui sinkronisasi beberapa moda di dalamnya. Teks semacam ini dapat berbentuk teks lisan atau cetak atau bahkan gambar bergerak yang dihubungkan dengan suara. Walsh juga memberikan contoh teks multimodal yang mudah didapatkan seperti film dokumenter, bahkan permainan daring atau game online dapat menjadi sumber multimodal teks. Dengan demikian, untuk mempercepat peningkatan kemampuan membaca maka seorang anak dapat dibiasakan untuk menggunakan teks multi moda yang dapat dipajankan melalui berbagai media.

Literasi di Indonesia dikembangkan dengan berbagai strategi dan cara, seperti misalnya didirikanya perpustakaan umum, perpustakaan mandiri, donasi buku oleh LSM, dan didirikanya Taman Baca Masyarakat (Håklev, 2010). Bukan hanya sekedar mencapai hasil PISA pada peringkat yang lebih tinggi, literasi di Indonesia dilakukan secara simultan baik di sekolah maupun di luar sekolah untuk menyadarkan masyarakat akan budaya belajar. Menurut Makin, dkk (2008, p. 57) dalam (Harris, Francis, College, \& Barker, 2011), disimpulkan bahwa kesadaran berliterasi telah berubah dan sudah saatnya anak-anak dipajankan pada perangkat komunikasi dan situasi yang bersifat multimodal daripada hanya sekadar pemaknaan secara linguistik. Dengan demikian diperlukan bentuk baru pendekatan literasi, dan salah satunya melalui pemanfaatan media teknologi seperti komputer sebagai sarana menambah media cetak yang selama ini biasa dipergunakan.

Bersamaan dengan kesadaran untuk mempropagandakan kemampuan memahami multi moda teks maka belajar tidak lagi cukup didefinisikan sebagai aktifitas psikokognitif. Melainkan belajar disikapi sebagai upaya "membiasakan" tindakan pemerolehan pengetahuan-kecakapanketerampilan, dengan demikiankepandaian dan kesuksesan menukik ke kedalaman teks-teks multi 
genre-multimedia dan menangkap spectrum maknanya. Hal ini hanya akan bias dibentuk melalui "pembiasaan" mengenali dan membaca teks-teks tersebut.

Mengandalkan proses membiasakan dan membisakan tidaklah cukup apabila hanya mengandalkan kegiatan belajar formal di sekolah (Ibrahim, 2017).Dibutuhkan upaya simultan yang dapat mempercepat tercapainya peningkatan kemampuan seseorang untuk memahami melalui pembiasaan membaca teks dengan ragam atau genre yang bervariasi. Peran keluarga dan masyarakat menjadi penting dalam menciptakan atmosfir belajar di luar sekolah. Taman Baca Masyarakat atau perpustakaan umum menjadi laboratorium yang dapat digiatkan untuk mendongkrak terbentuknya masyarakat yang menyadari kebutuhan akan kebiasaan untuk membaca dan kebisaanya memahami wacana. Keluarga menjadi poros yang akan melahirkan kebiasaan dalam ranah yang lebihsempit.

Belajar sepanjang hayat dipilih sebagai gagasan yang akan mendukung terbentuknya pembiasaan dan kebisaan yang diawali dari aktifitas belajar di luarsekolah. Tepatnya, belajar sepanjang hayat adalah suatu konsep, suatu ide, gagasan pokok yang dalam konsep artikel ini dipahami sebagai upaya belajar yang tidak hanya berlangsung di lembaga-lembaga pendidikan formal melainkan proses belajar yang terus berlangsung sekalipun seseorang seseorang tidak lagi mengikuti pendidikan di suatu lembaga pendidikan formal. Sehingga dapat ditekankan bahwa belajar dalam arti sebenarnya adalah sesuatu yang berlangsung sepanjang kehidupan seseorang.

Artikel ini ditulis sebagai bentuk pelaporan hasil pengabdian kepada masyarakat. Dalam kegiatan pengabdian ini ide pembiasan dikawinkan dengan ide pembisaan melalui aktifitas membaca dengan konsep belajar sepanjang hayat. Secara konkrit, pengabdian ini diarahkan untuk memberdayakan TBM yang akan dijadikan sebuah laboratorium dimana di tempat ini segala macam bentuk perlakuan atau uji coba untuk meningkatkan kebiasaan dan kebisaan membaca menjadi bagian hidup masyarakat dan keluarga dari sebuah lingkungan.

\section{PERUMUSAN KONSEP DAN STRATEGI KEGIATAN}

Pengabdian ini dilaksanakan dengan target peserta berasal dari wilayah radius 2 kilometer dengan Institut Teknologi Sepuluh Nopember (ITS) tepatnya di TBM Kelurahan Kejawan Putih Tambak, TBM RW 04 Kejawan Putih Tambak, TBM RW 03 Keputih, TBM Rusunawa Keputih, dan TBM RW 03 Gebang. Konsep laboratorium sepanjang hayat dimaknai sebagai upaya mempropagandakan pembiasaan dan pembisaan belajar yang akan mengadopsi model literasi dengan memanfaatkan muliti moda teks. Media teknologi dimanfaatkan untuk memperoleh multi mode teks yang terdapat pada telepon genggam (digital teks).

Multimoda teks dipajankan melalui kegiatan membaca berbagai format teks yang meliputi teks dari bacaan yang bersumber dari cerita anak baik fiksi maupun non fiksi. Cerita fiksi terdiri dari cerita rakyat, fabel, dan dongeng. Sedangkan cerita non fiksi diambil dari berbagai sumber dalam bentuk ensiklopedia dan buku pelajaran. Dengan sumber bacaan yang berbeda yang disajikan dalam kegiatan maka peserta program yang terdiri dari anak-anak usia sekolah dasar diajak untuk melatih kemampuannya memahami makna dari teks dengan berbagai ragam teks.

Bukan hanya sekedar mengajak membaca, kegiatan ini mengajak anak-anak melatih kemampuan mengingat dan menguatkan metakognisinya melalui kognitif proses (Cognitive process). Informasi yang diperoleh dari kegiatan membaca diikatkan kedalamretensi memori jangkapanjang tanpa harus memaksakan proses rote-learning yaitu belajar dengan menghafal, melainkan melalui kegiatan pembelajaran bermakna yang dilakukan aktifitas yang berulang dan mempraktikkan pengetahuan atau ilmu dalam dalam kehidupan nyata. Strategi yang dipergunakan untuk kebutuhan ini adalah degan cara mengajak anak-anak mereproduksi cerita yang telah dibacanya. Mereproduksi cerita dilakukan dengan cara menceritakan kembali cerita yang bersumber dari buku yang dibacanya kepada orang disekitarnya (kawan, guru, dan/atau orang tua). 
Pengenalan multi moda teks diperkenalkan tidak hanya melalui materi cetak melainkan juga memanfaatkan teks lisan yang ditemukan dalam sumber referensi daring (seperti youtube). Pemanfaatan youtube yang diakses melalui ponsel menjadi media memperkenalkan jenis ragam teks yang memiliki gerak dan suara. Keterampilan menyimak menjadi sasaran untuk dilejitkan melalui media dan aktifitas ini.

Kegiatan yang terakhir adalah pembuatan majalah dinding bertema. Kegiatan ini memiliki tujuan untuk mengintegrasikan karya seni, perkembangan bahasa dan literasi. Majalah dinding atau mading menjadi media unjuk karya yang menjadi sarana untuk menuangkan kreatifitas dan merupakan implementasi dari pengembangan keterampilan yang menstimulasiberkembangnya Higher-Order Thingking Skills seperti yang dipopulerkan oleh Bloom Taksonomi. Ini merupakan representasi kemampuan tingkat tinggi dimana peserta mampu menghasilkan karya sebagai hasil kegiatan membacanya. Bahkan secara psikologis, bentuk kegiatan ini dapat dimanfaatkan untuk melejitkan harga diri anak-anak yang diharapkan akan melahirkan kepercayaan pada diri sendiri.

\section{HASIL PENGABDIAN DAN PEMBAHASAN}

Kegiatan yang pertama dilakukan adalah kegiatan dengan tujuan untuk memberikan pajanan terhadap multimoda teks kepada peserta pengabdian. Kegiatan ini dilakukan melalui pendekatan membaca nyaring atau lantang (Read aloud). Membaca Nyaring atau lantang dipilih sebagai metoda pembiasaan dan pembisaan awal mengingat metode memiliki empat elemen dasar Wright (2007) dan Mantei \& Kervin (2018) sebagai sarana interaksi antar dan antara pembaca dan pendengar ketika dibacakan nyaring, sebagai sarana untuk meningkatkan jumlah kosa kata, serta menjadi sarana untuk memperkenalkan bunyi kata dan pengucapannya. Dalam penelitian keduanya, juga disebutkan bahwa membaca nyaring dapat meningkatan kemampuan anak untuk memahami teks lisan dan juga merupakan media memahamkan sintaksis yang terdapat dalam teks dan konteks dari sebuah wacana. Yang paling penting membaca nyaring meningkatkan emergent literacy atau kemampuan literasi bawaan yang dimiliki sebelum seorang menerima beragam perlakuan atau pembelajaran.

Dalam kegiatan membaca nyaring, anak-anak diberi kesempatan memilih bacaan yang sesuai dengan minatnya. Hal ini penting mengingat kegiatan membaca tidak boleh dilakukan untuk menekan atau membebani anak, melainkan sebaliknya menyadarkan pada anak bahwa membaca dapat menjadi aktifitas yang menyenangkan. Tim pengabdi mendemonstrasikan membaca nyaring (lihat gambar 2) untuk memberikan model yang dapat diikuti oleh peserta pengabdian.

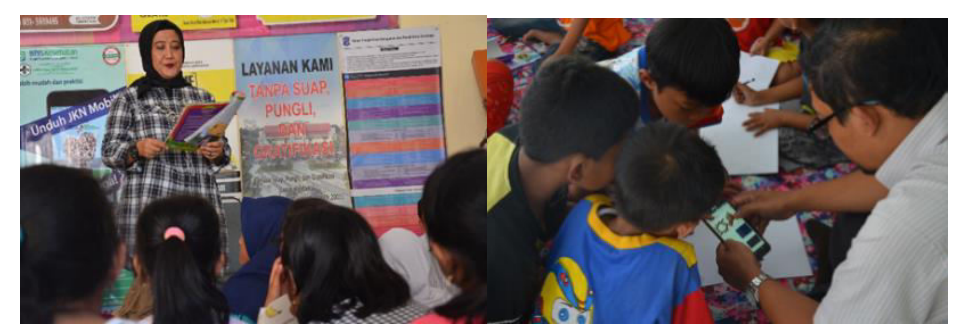

Gambar 2. Model Membaca Nyaring dari ragam multi moda teks (cetak dan digital)

Selanjutnya, peserta pengabdian diberi kesempatan untuk berlatih membaca nyaring di hadapan peserta yang lain dengan didampingi oleh tim pengabdi (lihat gambar 3 ). 


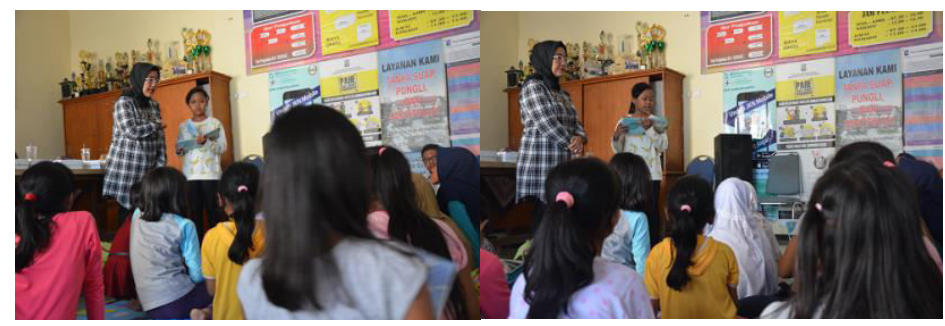

Gambar 3. Peserta Pengabdian Membacakan Nyaring

Untuk memberikan kesempatan pada setiap peserta pengabdian, maka pengabdi melakukan proses pendampinganberfokuspadakemampuanmembacanyaring dengan cara melatih mereka membaca nyaring dalam kelompok kecil (lihat gambar 4). Melalui proses ini, anak-anak dibiasakan dan dibisakan membaca cerita pendek dari buku yang dipilih sendiri. Kegiatan membaca nyaring dilakukan bersama-sama dalam kelompok secara bergantian. Salah satu membaca dan yang lain menyimak serta saat tertentu diperbolehkan bertanya untuk mengulangi bila ada cerita yang kurang jelas dimengerti. Bahkan pendamping juga diperkenankan membantu memberikan penjelasan. Kegiatan ini menggambarkan bahwa bagaimana sebuah kegiatan membaca nyaring dapat memberikan ruang untuk interaksi dua arah antara pembaca, pendengar, dan pendamping. Hal ini seperti yang tersebut dalam tulisan Wright, (2007)dan Mantei \& Kervin (2018) bahwa kegiatan ini adalah efektif untuk meningkatkan interaksi dan selanjutnya menumbuhkan kesadaran berliterasi.

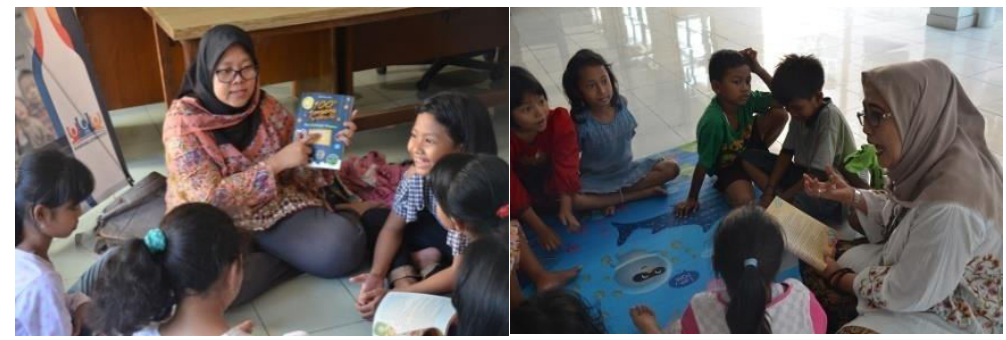

Gambar 4. Pendampingan Membaca Nyaring

Selain membaca nyaring yang lebih banyak memanfaatkan media cetak, menyimak menjadi aktifitas yang didesain untuk memperkenalkan jenis multi moda teks melalui media nirkabel. Youtube dipilih sebagai salah satu sumber belajar yang menyediakan jenis teks ini (lihat gambar 5). Dua jenis kegiatan ini bertujuan untuk memancing daya imajinasi dan melahirkan ide kreatif yang akan dibutuhkan oleh peserta pengabdian pada kegiatan selanjutnya yaitu mereproduksi cerita.

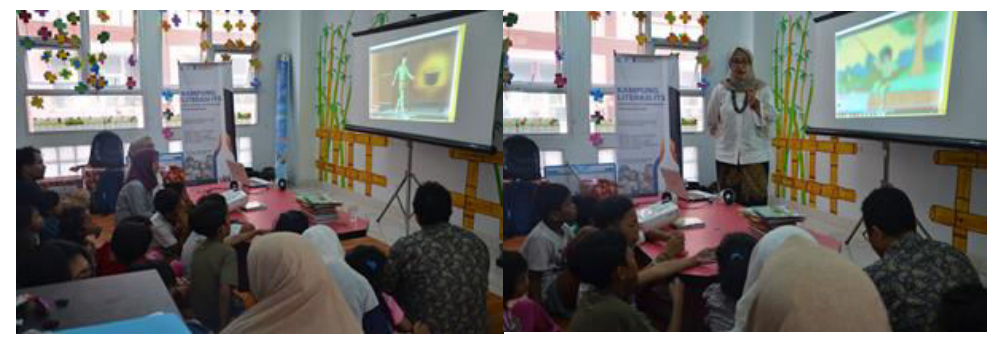

Gambar 5. Multi moda teks melalui pemutaran film

Dua jenis kegiatan diatas diarahkan untuk menghasilkan sebuah luaran yaitu cerita yang ditulis oleh anak-anak peserta pengabdian. Seperti yang tersebut diatas bahwasannya aktifitas 
menulis cerita merupakan pelatihan strategi belajar yang menekankan pada kebermaknaan terhadapinput yang diperoleh (meaningful learning), dan beberapa ahli berpendapat bahawa strategibelajar ini lebih efektif dibandingkan dengan belajar yang mengandalkan hafalan (rote learning). Kegiatan ini melatih anak-anak mengingat dan mengikat informasi untuk meningkatkan retensi ingatan seseorang seperti yang ada dalamkonsep meaningful learning. Dengan demikian diperlukan cara menerima input melalui proses kognitif (Cognitive process)(Mayer, 2002).Melalui pendampingan, setiap siswa diajak membaca dimana melalui aktifitas membaca ini anak-anak akan mempereh kosa kata baru beserta dengan bagaimana mereka dipergunakan dalam konteks, selanjutnya bacaan yang telah selesai dibaca menjadi sumber ide untuk mengembangkan cerita mereka sendiri. Anak-anak dapat memanfaatkan kosakata yang baru diperolehnya kedalam cerita yang diciptakan. Disinilah pembelajaran menjadi bermakna dan sesungguhnya aktifitas ini melatih anak-anak mengelola input dan menjadikan input tersebut menjadi pengetahuan yang baru. Proses kognitif ini telah efektif berjalan dengan dihasilkannya 100 cerita anak dimana 30 cerita merupakan cerita yang layak publikasi. Kumpulan 30 cerita anak terbaik tersebut diterbitkan dan layak dipasarkan (lihat gambar 6).

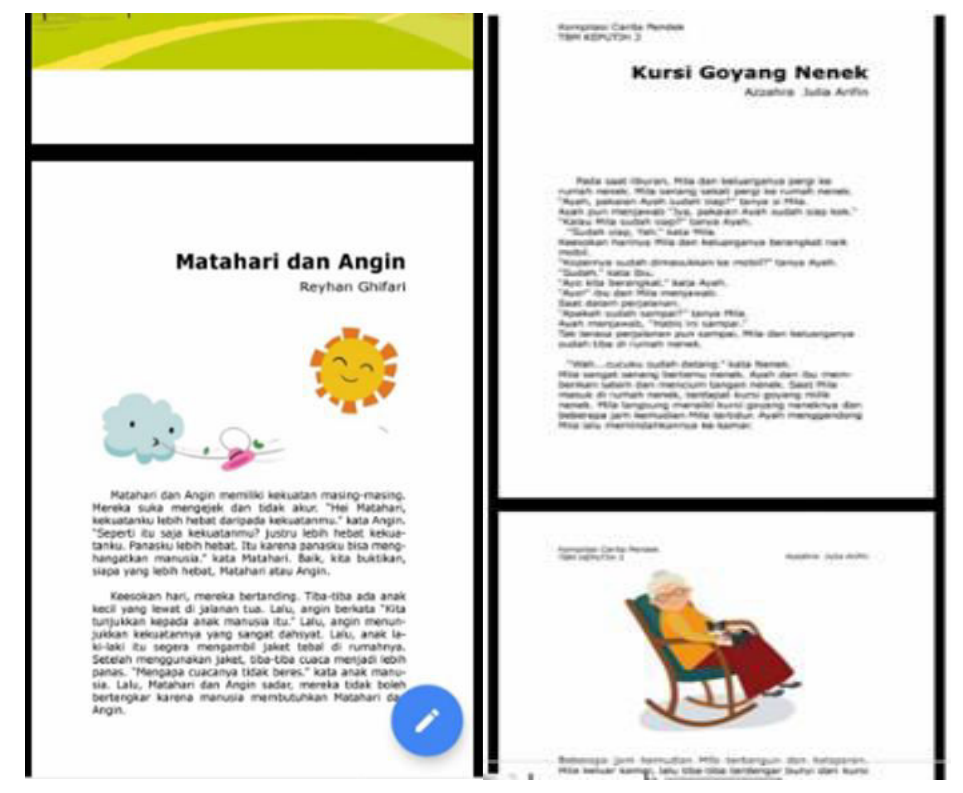

Gambar 6. Contoh kumpulan cerita

Sebagai bentuk aktifitas yang lain adalah pembuatan majalah dinding. Tim pengabdi mengajak anak-anak peserta pengabdian untuk membuat majalah dinding dengan tema tertentu. Sesungguhnya dalam majalah dinding beberapa unsur terintegrasi secara sempurna. Seperti pernyataan Moore and Caldwell (1993)dalam Hutchison \& Hornsby (2008) bahwa kreatifitas dapat ditumbuhkan dengan menginterkoneksikan antara karya seni dan pembelajaran bahasa. Pada pembuatan mading peserta pengabdian diajak menggambar dan membuat prakarya yang selanjutnya diintegrasikan dengan membuat cerita atau deskripsi yang bertautan dengan hasil karya seni tersebut sehingga menjadikan majalah dinding sebuah teks bergambar yang lahir dari kreatifitas anak-anak pada saat yang sama menjadi stimulasi berkembangnya kesadaran literasi mereka.Pengabdian ini memberikan bukti empiris bahwa dengan melibatkan atau memanfaatkan pekerjaan seni sebagai media menstimulasi kemampuan kebahasaan seorang anak, maka kesadaran literasi pun berkembang. Dengan demikian seperti Hutchison \& Hornsby, (2008), pengabdian ini melalui aktifitas pembuatan majalah dinding mampu mendorong perkembangan psikomotoris 
mengingat anak-anak harus bergerak dengan tubuhnya untuk mengunting, menggambar, mewarnai, serta menempel. Pada saat yang sama afeksinya pun ditempa dengan berlatih bekerja sama, menghargai karya kawannya dan mengembangkan rasa keindahan dan seni ketika mendesain tata letak mading. Kegiatan ini mengintegrasi perkembangan bukan hanya kognisi saja melainkan psikomotorik dan afeksi anak (gambar 7).

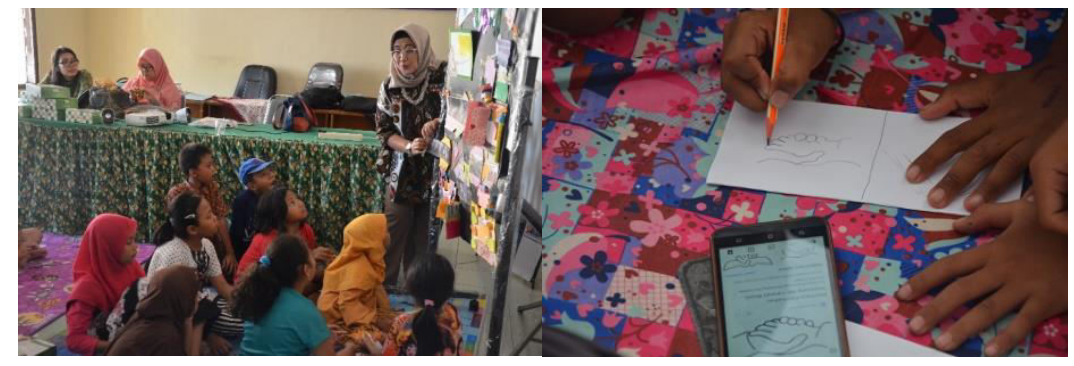

Gambar 7. Membuat Mading Tematik

\section{KESIMPULAN}

Rangkaian kegiatan pengabdian ini membuktikan bahwa upaya optimalisasi peran Taman Baca Masyarakat merupakan strategi efektif untuk meningkatkan kemampuan literasi masyarakat kota Surabaya. Pemanfaatan multi modal teks yang diberikan melalui media cetak dan daring menunjukkan kesangkilan untuk mendorong anak memiliki kebiasaan dan kebisaan membaca, hal ini sejalan dengan hasil temuan Harris dkk. (2011) dan Danielsson \& Selander (2016). Melalui kegiatan membaca nyaring, menulis cerita dan membuat mading tematik, Taman Baca Masyarakat memiliki tingkat probabilitas yang tinggi untuk dijadikan laboratorium belajar sepanjang hayat. Ketiga jenis kegiatan yang dimodelkan oleh tim pengabdi telah mengintegrasikan melejitnya kemampuan kognitif, afektif, dan psikomotor anak-anak, sehingga pada saat yang sama kebiasaan dan kebisaan belajar bukan menjadi hal yang tidak dapat distimulasi. Bersama berkembangnya kebiasaan dan kebisaan membaca maka belajar akan menjadi kebutuhan dimana TBM yang akan menjadi sentra belajar anak-anak yang tinggal di wilayah sekitar TBM. Dalam upaya jangka panjang kondisi ini apabila dipertahankan, maka kekhawatiran akan tingkat literasi negara kita, khususnya pada ranah membaca, dapat ditekan.

\section{DAFTAR PUSTAKA}

Danielsson, K., \& Selander, S. (2016). Reading multimodal texts for learning - a model for cultivating multimodal literacy. Designs for Learning, 8(1), 25-36. https://doi.org/10.16993/dfl.72

Foy, P. (2017). USER GUIDE FOR THE INTERNATIONAL DATABASE TIMSS 2015 Works User Guide for the International Database.

Foy, P., Aldrich, C. E. A., Fishbein, B. G., Köhler, H., Kowolik, K., Liu, J., ... Yin, L. (2018). PIRLS 2016 User Guide For The International Database.

Håklev, S. (2010). Community Libraries in Indonesia : A Survey of Government- Supported and Independent Reading Gardens Higher Education and Comparative, International and Development Education Ontario Institute for Studies in Education University of Toronto. Library Philosophy and Practice, 2010, 1-17.

Harris, A., Francis, S., College, D. S., \& Barker, M. (2011). How Effective are Print-Based Comprehension Models for Reading and Assessing Multimodal Texts ?, 19-33. 
Hutchison, K., \& Hornsby, D. (2008). Creative pedagogies: "Art-full" reading and writing AUDREY GRANT, 7(1), 57-72.

Ibrahim, G. A. (2017). PISA dan Daya Baca Bangsa. Kompas.Com, p. 7.

Jones, S. K. (2015). Authenticity and Children 's Engagement with Writing, 17(1), 63-83.

Mantei, J., \& Kervin, L. (2018). Examining literacy demands for children during teacher-led episodes of reading aloud across the transition from Preschool to Kindergarten, 41(2), 82-94.

Mayer, R. E. (2002). Rote Versus Meaningful Learning 1, 41(4), 226-233.

OECD. (2018). PISA 2015: Results in focus. Pisa 2015, (67), 16. https://doi.org/10.1787/9789264266490-en

Walsh, M. (2003). Reading visual and multimodal texts: how is 'reading'different? Proceedings of the ALEA/UNE 2004 Conference," Multiliteracies and English $\mathrm{K}-12$ in the Age of Information and Communication Technologies 2004, (May), 25-27. Retrieved from http://www.literacyeducators.com.au/docs/Reading multimodal texts.pdf

Wright, T. L. (2007). Maximizing the effectiveness of reading aloud, 668-675. https://doi.org/10.1598/RT.60.7.7 